\title{
Destination Networks as a Tool for Minimizing the Risk and Improving the Performance of a Destination
}

\section{Andrea Holešinská, Markéta Bobková}

e-mail: holesinska@econ.muni.cz, mar.novotna@mail.muni.cz

Faculty of Economics and Administration, Masaryk University, Brno, Czech Republic

Holešinská, A., \& Bobková, M. (2015). Destination Networks as a Tool for Minimizing the Risk and Improving the Performance of a destination. Czech Journal of Tourism, 4(2), 91-102. DOI: 10.1515/cjot-2015-0006

\begin{abstract}
The management of a tourist destination in the form of networks is considered to be one of the possible approaches to destination governance structures. The concept of destination governance is based on the cooperation between actors from the public and private sectors. It is known that public-private relationships built on trust, joint risk taking and based on informal structures have a positive impact on the level of growth at a tourist destination. The aim of this paper is to quantify to what extent each of the determinants of the DMO success participate in the total destination performance, and thus point out the factors of a potential risk.

The main objective of this paper is the cooperation between the destination management organization (DMO), public sector and entrepreneurs providing tourism services. The data collection was achieved by conducting in-depth interviews and structured questionnaires. The analysed data identify the factors of successful mutual cooperation that are used as inputs for further modelling. The contribution of the paper lies in the application of the total quality management concept methodology to identify the share of each factor/determinant in the DMO performance.
\end{abstract}

\section{Keywords}

DMO, networks, cooperation, performance, Czech Republic

JEL classification: L83, M14, L22 


\section{Introduction}

In the present world, full of changes (economic crises or natural disasters) destinations are much more forced to plan and control their activities effectively. In this process, strategy has the key role. Its purpose is to secure destination competitiveness. The success of the destination (respectively, the DMO performance), is then significantly influenced apart from a good strategy by the participation of stakeholders in the form of coordinated cooperation (Holešinská, 2007), which is experienced within the framework of networks (Volgger \& Pechlaner, 2014). Hence, networking is considered as a good way to strengthen the society and improve the economic growth. In this way, the destination networks can function as a tool for defusing crises and on the contrary, as a tool enhancing the performance itself (competitiveness) of the destination.

Thus, the research question is as follows:

- How do the factors of cooperation within a network determine the destination management organization performance?

\section{Theoretical basis}

The small business structure of tourism businesses has become a real disadvantage (Pechlaner \& Tschurtschenthaler, 2003), which requires a behaviour change and more cooperative actions including various types of partnership, alliance or networks between the actors of the society (Halme, 2001). The entrepreneurial efforts to encourage the innovation and development are connected with a substantial share of the financial risk (Ritchie \& Crouch, 2003, p. 141). This risk for small individual enterprises is combined with negative externalities (Weiermair, Peters \& Frehse, 2008). All these circumstances pose a challenge for tourism organisations, which have a key position in overcoming the crisis of tourism (Pechlaner \& Tschurtschenthaler, 2003).

Wang and Fesenmaier (2006) say that the crisis is one of the most important preconditions and network-oriented motivation for the tourism organizations to form collaborative relationships, especially when the crisis requires a collective action. A glowing example is the case of the Alpine regions (Pechlaner \& Tschurtschenthaler, 2003) where the stimulus for the collective action came in the last quarter of the $20^{\text {th }}$ century from the structural economic changes (e.g. globalisation), as well as from the dynamic changes on the demand side (rapidly changing customer needs). All this made pressure on the destination (individual stakeholder) competitiveness, and thus the networks started to operate.

The cooperation within the networks is the issue of many researchers (e.g. Tinsley \& Lynch, 2001; Grängsjö \& Gummesson, 2006; Kylänen \& Rusko, 2011; or Beritelli, 2011). The basic idea of the network theory that the access to the network is an advantage for all the other participants in the network strongly influences competitive strategies and achievements (Page \& Lopatka, 1999). Nordin and Svensson (2007) perceive the network as a means of coordination, which is based on mutual trust, risk sharing, informal structures and strategic consensus. Beritelli (2011) considers the networks as an implicit 
process based on communication and mutual trust that is related to the so-called explicit process that has the legislative and institutional framework. Chen and Tseng (2005) believe that destination stakeholders are forced to cooperate by the rising competitiveness and overcoming crisis. In this case, networking is considered as a good way to strengthen the society and improve the economic growth.

The networks are made up of various stakeholders who have their own goals and strategies; however, when achieving the desired outcomes of public policy, they are interdependent. The network varies depending on the distribution of powers and the institutional framework (Bovaird \& Löffler, 2009). Erkus-Öztürk (2008) focuses on the role of firm size in designing the level of network relations. He claims that small firms tend to be lifecycle entrepreneurs who rarely even consider themselves as a part of the industry. Due to their small size, they can easily adapt to the crisis conditions. The relations in the network could be influenced by the insufficiently defined responsibility, mutual competition and poor communication (Dredge, 2006). Therefore, a lack of communication between the destination stakeholders poses a substantial risk for the destination.

According to Chang (2009), risks in tourism stem from two main sources: a lack of knowledge about the tourism destination, and a lack of knowledge of future conditions. According to Swarbrooke (2005), tourism should concentrate on the unique features of the country to reduce the risk of competition from other destinations. Kozak, Crotts, and Law (2007) claim that the destination image in terms of risk and safety has a deterring impact on the likelihood of international visitors. Careful planning and management are required to ensure proper balance between the growth of tourism and the development of infrastructure and other facilitating resources. Without such a balance, economic, social, ecological and perhaps even political systems might be placed at risk (Ritchie \& Crouch, 2003, p. 70).

The advantages of the networks leading to ensuring the mentioned balance and making a destination competitive can be segmented into the following benefit categories: learning and exchange (including the knowledge transfer, tourism education process or communication), business activity (marketing, purchasing, trading within the network, opportunities for business development interventions) and community, including the community support for destination development, fostering the common purpose or engagement of SMEs in destination development (Gibson \& Lynch, 2007).

As far as the destination competitiveness is concerned, Volgger and Pechlaner (2014) confirm the positive correlation between the DMO success and the destination success. The networking capability tends to exert a positive effect on the DMO success by increasing the authority of the DMO within the destination network. The destination success consequently induces the outputs in the form of competitive product, customer satisfaction and sustainability. Their determinants of the DMO success can be extended by Holešinská (2007) who highlights the 3C-principle leading to a successful application of the destination management process and identifies external and internal factors influencing the DMO performance. Whereas the internal factors arise from the interactions between the stakeholders, the external factors are associated with the political environment. This 
political environment affects important factors of the DMO success, which are authority and acceptance. All these factors are schematically shown in Figure 1.

Fiqure 1 Model of the determinants of the DMO successful performance

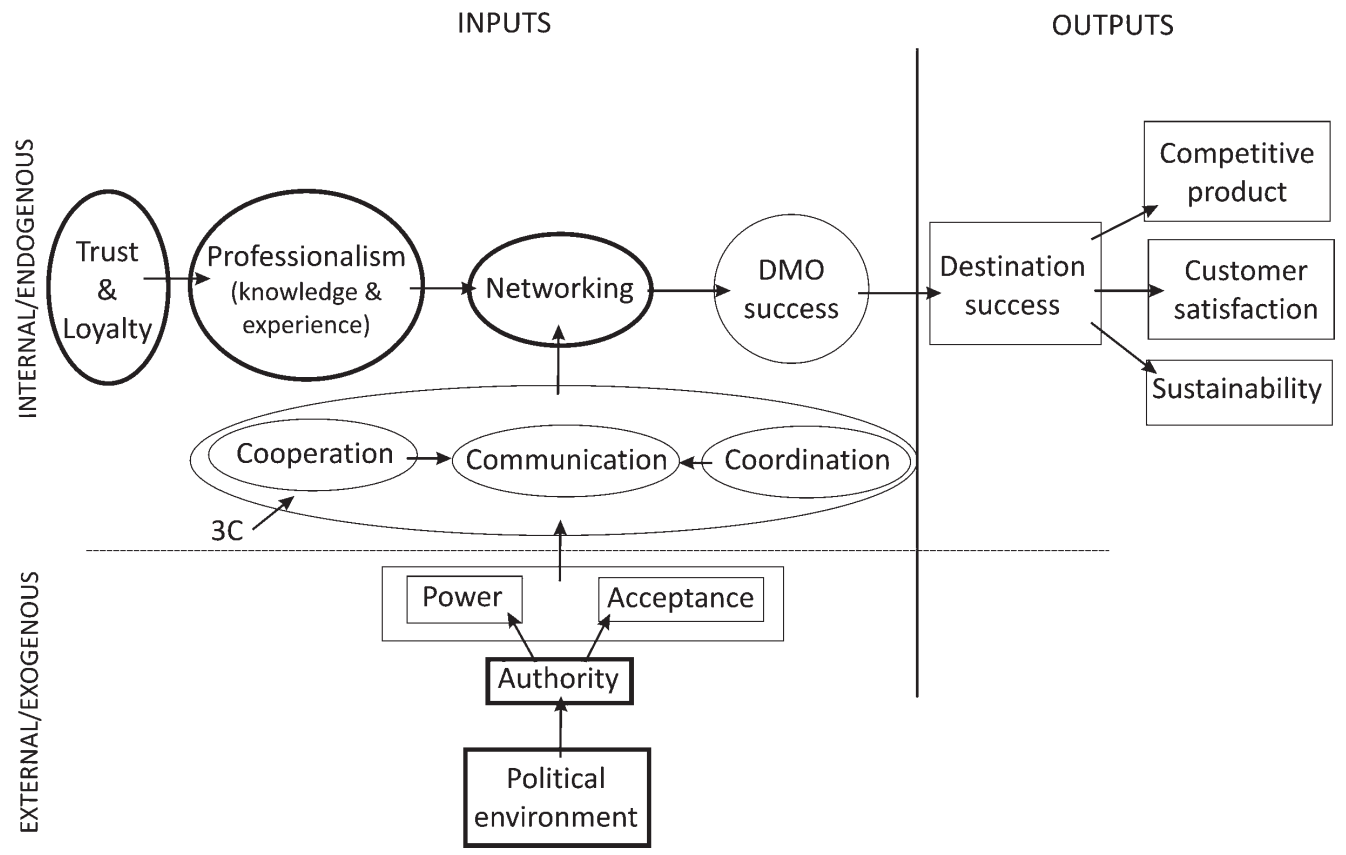

Source: authors', based on Holešinská (2007), and Volgger and Pechlaner (2014)

The introduced schema can be likened to the EFQM Excellence Model and models of the Total Quality Management which represent an approach to the long-term success and improving the performance of tourist destinations (Kozak \& Baloglu, 2011). The EFQM Excellence Model is made up of nine elements grouped under enabler criteria (leadership, policy and strategy, people, partnerships and resources and processes) and result criteria (people results, customer results, society results and key performance results) with a relative weight. It can be used by an organization to identify its opportunities and current strengths with a positive impact on the potential destination competitiveness.

Moreover, the linkage between the EFQM Excellance Model and the Model of the determinants of the DMO successful performance in Figure 1 lies in the close relationship between its components (factors). When something is wrong with any of these factors, the outcome can be negative and therefore they can pose a potential risk for the DMO successful performance. 


\section{Methodology}

To be able to answer the research question, the methodology of the EFQM Excellence Model is implemented to measure the probability of each of the determinants involved in the process of networking which is the fundamental step of the DMO success (Figure 1). Or other way round, to measure the probability of a potential risk that can affect the destination management organization's performance. The research focuses on 5 key inputs determinants - two external (political environment and authority) and three internal (trust, professionalism and networking). To compare these determinants (factors) and estimate their outcome, the percentage weights are used. The level of every key determinant has 100-precentage within the whole model. The calculation of the percentage share (ps) of the examined determinant is as follows:

$$
\mathrm{ps}=[(\mathrm{n} \times 4) \times 100] / \Sigma \mathbf{x} .
$$

The lower percentage share is, the higher risk is posed.

The respondents were asked to evaluate the factors of successful partnership as the foundation stone of the DMO success. The evaluation scale was from 1 (negligible) through 4 (fundamental). The data were measured on the ordinal scale and all five factors were not independent on each other. Therefore Friedman ANOVA was used to test potential differences among 5 factors appearing in the model. The multiple comparison was applied after Friedman ANOVA.

The model was tested on the data collected within the case study which was based on in-depth face-to-face interviews and structured questionnaires distributed by e-mail. The survey was performed in two most visited resorts of the East Moravia region in the Czech Republic. It addressed more than 200 subjects from both public and private sectors that provide tourism product/services. The portfolio of the addressed subjects includes 1 regional DMO, 8 key business partners of DMO and other 193 tourism service providers (stakeholders) that are listed in the DMO's database.

Because of the continuing process of the research, the model is pre-tested on the semidata. Thus, the research sample consists of 22 items (1 regional DMO, 8 key business partners, 11 tourism service providers, who filled in the questionnaire). Table 1 shows the distribution of the questionnaires and the responses.

Table 1 Distribution of the questionnaires and their responses

\begin{tabular}{|l|c|c|}
\hline Reaction & $\mathrm{n}$ & $\%$ \\
\hline Complete response & $\mathbf{1 5}$ & $\mathbf{7 . 8}$ \\
\hline Partial response & $\mathbf{7}$ & $\mathbf{3 . 6}$ \\
\hline Interested but no response & 28 & 14.5 \\
\hline Uninterested and no response & 33 & 16.6 \\
\hline
\end{tabular}




\begin{tabular}{|l|c|c|}
\hline Reaction & $\mathbf{n}$ & $\%$ \\
\hline Unable to contact & 103 & 53.4 \\
\hline For sale & 8 & 4.1 \\
\hline & 193 & 100 \\
\hline
\end{tabular}

Source: authors' research (2015)

\section{Case study description}

The major argument for selecting the East Moravia region as the object of the research and the presented case study is that the region is managed by one of the most developed regional destination management organization (DMO) in the Czech Republic (Holešinská, 2012). The Tourist Authority of the East Moravia (DMO) was established in 2007 and since the beginning it has been run as a business unit rather than a public administration, which is still common in the Czech Republic (Holešinská, 2012, 2013). The East Moravia region is diverse in many aspects and therefore it is demanding for coordination and cooperation. This makes the region interesting for studying the community networks and their participation in the destination success.

The East Moravia region is situated in the eastern part of the Czech Republic, along the border with Slovakia. The region has very good prerequisites for tourism (Figure 2). It offers a varied spectrum of landscape scenery and many cultural and historical sights. It is well-known for its folklore tradition. Therefore the region can be identified as a cultural melting pot.

For the purpose of this case study, two attractive and the most visited tourist resorts were selected (Table 2). The first one is the spa resort Luhačovicko (more than 4,000 beds in collective accommodation establishments) and the second one is the mountain resort Vsacko (more than 2,000 beds). Luhačovicko is the resort with the largest Moravian spa, which has a long tradition and typical architecture. It is the fourth largest spa in the Czech Republic. The mountain resort Vsacko offers high mountains of the region, various customs and traditions, as well as unique folk architecture monuments. The region is known for its local hospitality.

Table 2 Characteristics of Luhačovicko and Vsacko tourist resorts

\begin{tabular}{|l|c|c|c|c|}
\hline Tourist resort & $\begin{array}{c}\text { Bed capacity } \\
\text { in CAE }\end{array}$ & $\begin{array}{c}\text { \% of East } \\
\text { Moravia }\end{array}$ & $\begin{array}{c}\text { Number of } \\
\text { overnights }\end{array}$ & $\begin{array}{c}\text { \% of East } \\
\text { Moravia }\end{array}$ \\
\hline Luhačovicko & 4,027 & 15.6 & 664,165 & 35.9 \\
\hline Vsacko & 2,197 & 8.5 & 147,609 & 7.9 \\
\hline
\end{tabular}

$\mathrm{CAE}=$ collective accommodation establishment

Source: Czech Statistical Office (2015) 
Figure 2 The map of the East Moravia region and Luhačovicko and Vsacko tourist resorts

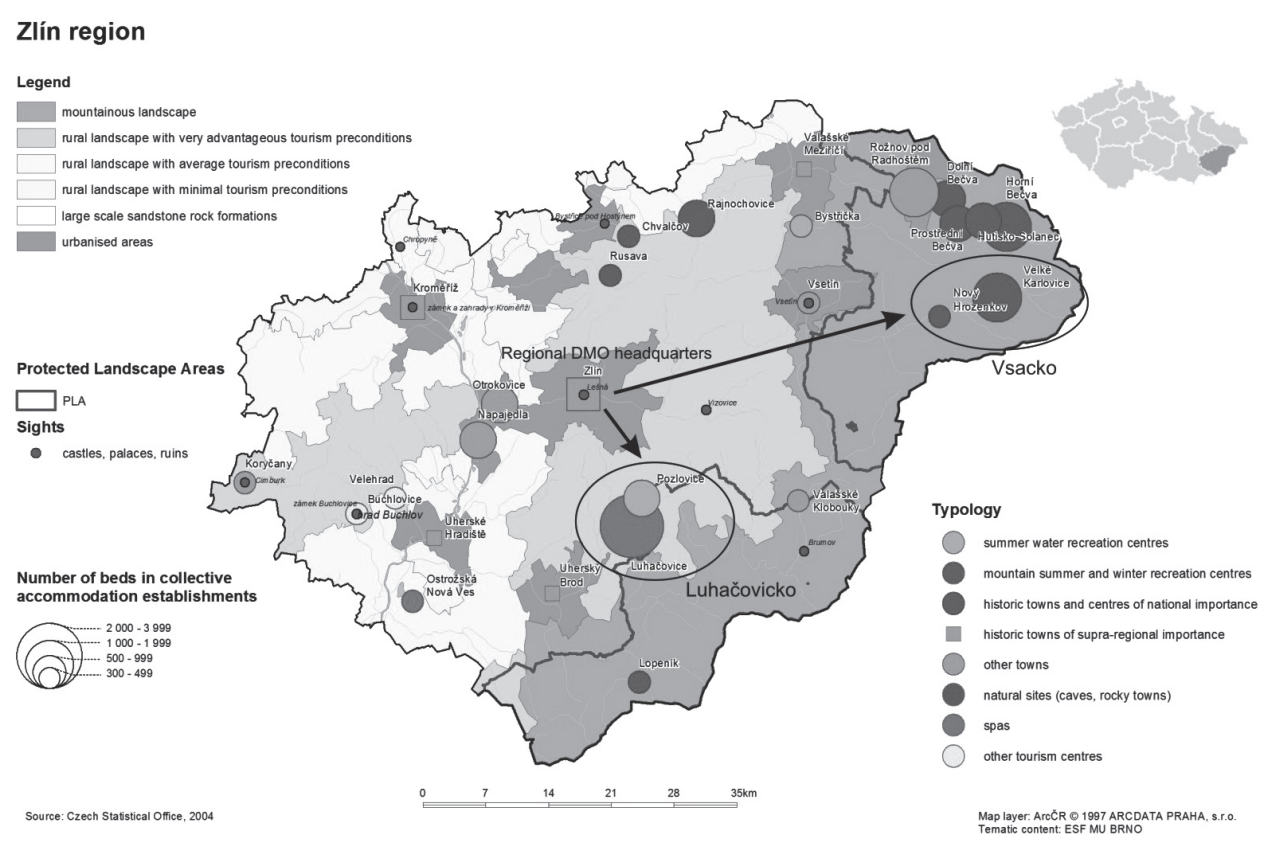

Source: Vystoupil et al. (2006)

\section{Results}

Most of the respondents agree that the determinants Trust and Networking are the most important (fundamental) factors influencing the successful partnership, and thus they result in the DMO success.

Concerning the factor Networking, respondents' experience requires the need for the existence of common interest; for mutual communication; and for regular cooperation with hard and fast rules for all stakeholders. The requirement of setting clear rules of cooperation arises from the existence of distrust among stakeholders. The face-toface interviews reveal this fact. Another evidence of the fragile relationship or the (im) maturity of cooperation is shown in the list of the most-practised cooperative activities - information exchange and sharing; organising the participation at trade fairs; public relations; and monitoring. Even the frequency of communication when practising a certain activity is very low. This indicates that the partners are not sufficiently engaged in the cooperation.

As far as the factor Professionalism is concerned, more than half of all respondents considers it likely/the most important in terms of DMO success. The Authority is recognised to be also an important factor that determinates the successful partnership. 
The factor Political environment has the highest variability. In total, it is marked as negligible.

The validity of the data was tested. Figure 3 shows statistical differences among five measured factors (Friedman test $=22.197 ; \mathrm{p}<0.001 ; \mathrm{n}=22$, d.f. $=4$ ). It is evident that Networking and Trust obtained statistically more points than Political environment (multiple comparison after Friedman ANOVA, $\mathrm{p}<0.05$ ). The other differences were not statistically important.

Figure 3 Statistical differences among the measured factors/determinants

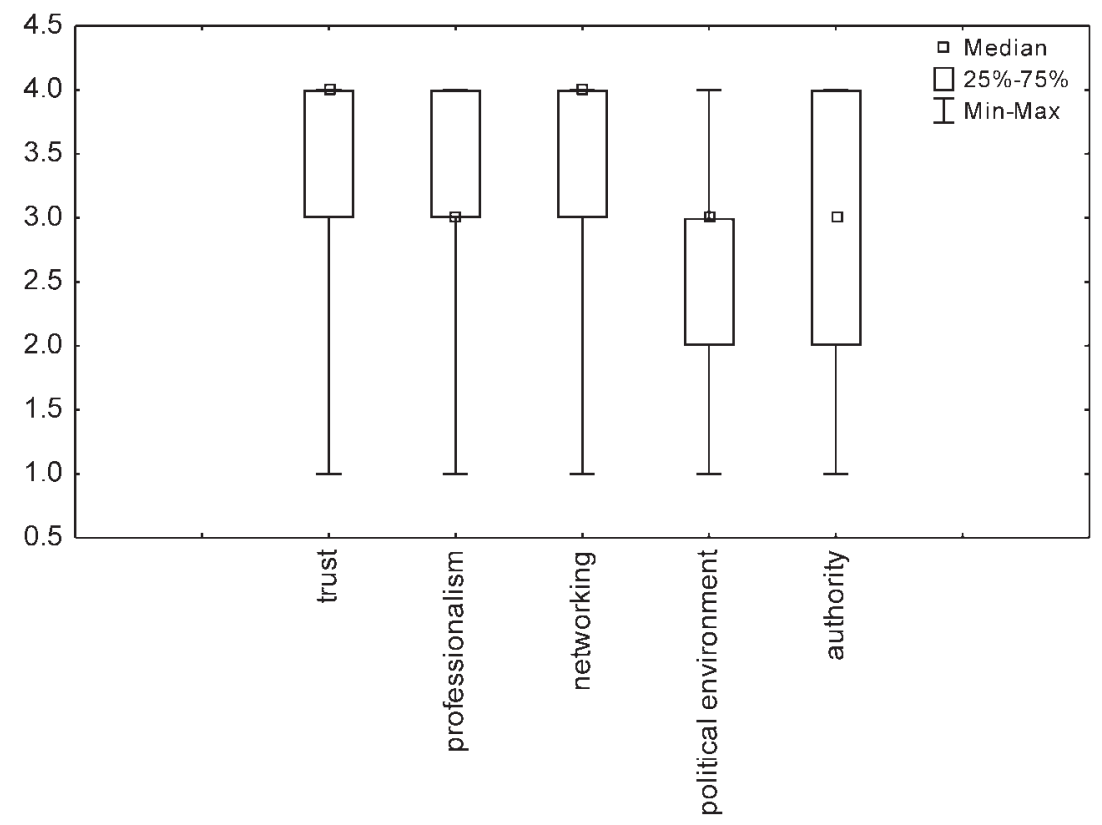

Source: authors' research (2015)

To put these results into the context of the potential risk for the DMO successful performance, the percentage share of each determinant was calculated (Figure 4). According to the case study, it is obvious that Networking is the key stone for the DMO success and in the current situation it represents "only" $11 \%$ of the potential risk. The same is true for Trust. In general, the internal inputs can be "easily" practised by stakeholders and therefore they cause less risk. On the contrary, the external inputs cause a higher risk, especially the political environment that creates the framework (e.g. organizational structure of governments, legislation), in which the communities (stakeholders and DMOs) operate. In this case, it has a negative outcome of $36 \%$.

Concerning the maximum level of each of the determinants, the results are not satisfactory. The regional DMO has still a lot of work to do. 
Figure 4 Importance of the determinants of the DMO success

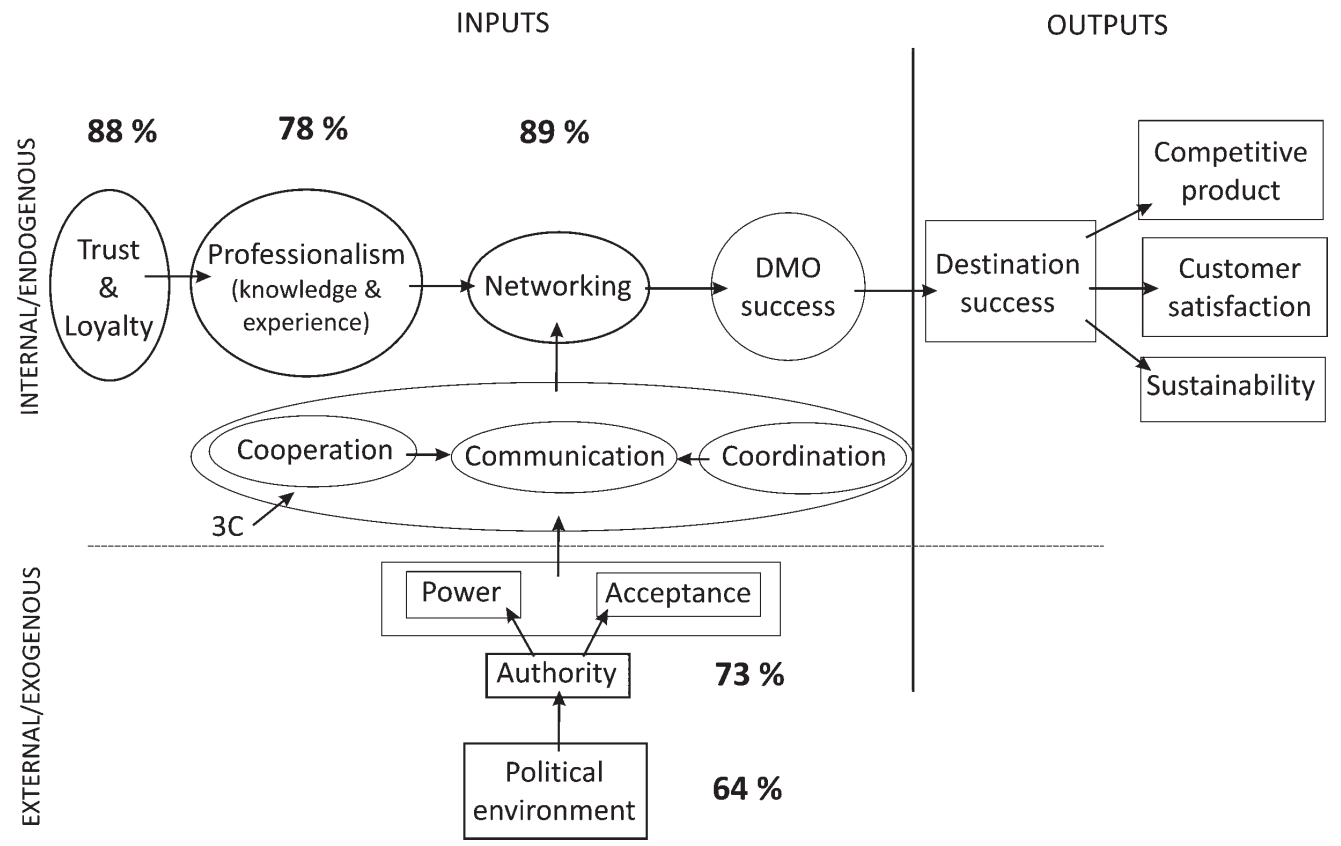

Source: authors' research (2015)

\section{Discussion}

The findings presented in this paper certainly verify the earlier research, e.g. the network is based on communication and mutual trust (Beritelli, 2011); the network is influenced by poor communication (Dredge, 2006); the network depends on the power and the institutional framework (Bovaird \& Löffler, 2009). In addition, the concept of the destination competitiveness is also important in this respect (e.g. Ritchie \& Crouch, 2003; Volgger \& Pechlaner, 2014). According to the literature review, an extended model of the determinants of the DMO successful performance is introduced. The model presents its components in two dimensions: input-output and internal-external.

Apart from the model, the contribution of this paper can be visible at least in two aspects. Firstly, the innovative point consists in the application of the total quality management concept methodology (Kozak \& Baloglu, 2011) to identify the share of each of the determinants in the DMO performance. Moreover, regardless of the fact that the relationship changes during the time and the needs of stakeholders change as well, the results enrich the existing knowledge and earlier research in the Czech Republic and in the Slovak Republic (Holešinská, 2007, 2012, 2013, 2014). 
Concerning the case study of the Czech Republic, the findings cannot be generalised, nevertheless, they help to better understand the situation, for example, the demand for setting clear rules of cooperation which arise from the mutual distrust among the stakeholders; or the most-practised cooperative activities that can be categorized into the growth phase of cooperation (Holešinská, 2013) and they are related to the external public financial resources from the EU funds. To obtain the EU funding, the DMOs are made to adapt their activities and very often these adapted activities do not meet the requirements of either stakeholders, or visitors. (Holešinská, 2012, 2013)

\section{Conclusion}

The model of the determinants of the DMO successful performance shows that Networking is the key component that hand in hand with Trust, stimulate the DMO success. The results indicate the areas of the improvement, both the regional DMO's performance and the competitiveness of the destination (East Moravia).

The potential risk for the DMO performance results from the external determinants, such as the political environment (including the conditions for obtaining public financial resources) and the authority of DMO. Unfortunately, both stakeholders and DMO must somehow cope with the external determinants. In case of the internal/endogenous determinants, it is possible to take own steps which can stimulate these determinants.

What are the suggestions for the regional DMO to strengthen its network and thus improve its own performance? Firstly, the regional DMO should reflect the requirements and needs of its stakeholders. The problem is that there is no coordinator or leader in the selected tourist resorts (spa resort Luhačovicko and mountain resort Vsacko). The improvement calls for the structural changes (see the community and business type of the destination - Bieger, Laesser, \& Beritelli, 2011).

Furthermore, the DMO should take actions that stimulate trust among the stakeholders or motivate the stakeholders to join the partnership and believe in it. This can be done by strengthening the DMO legitimacy through its activities that would be directly aim at the stakeholders, and by setting simple rules guaranteeing the stakeholders the same conditions.

Kozak and Baloglu (2011) state that there are also certain limits of the application of the TQM methodology concerning the different conditions in each destination. They provide an example of the organizational structure of governments. Another limitation of this study is connected with the data source that covers only the semi-data that are available at the time of publishing this paper. To obtain significant results,separate determinants should be tested, as well as the model as a whole.

\section{Acknowledgment}

This article was supported by the project Specific University Research at Masaryk University in Brno, Faculty of Economics and Administration, no. MUNI/A/1250/2014. 


\section{References}

Beritelli, P. (2011). Cooperation among prominent actors in a tourist destination. Annals of Tourism Research, 38(2), 607-629. DOI: 10.1016/j.annals.2010.11.015.

Bieger, T., Laesser, C., \& Beritelli, P. (2011). Destinationsstrukturen der 3. Generation: Der Anschluss zum Markt. St. Gallen: Universität St. Gallen. Retrieved from https://www.alexandria.unisg.ch/ export/DL/206538.pdf

Bovaird, T., \& Löffler, E. (2009). Public management and governance. Taylor \& Francis.

Chang, S. Y. (2009). Australians' holiday decisions in China: A study combining novelty seeking and risk-perception behaviors. Journal of China Tourism Research, 5(4), 364-387. DOI: $10.1080 / 19388160903382533$.

Chen, H. M., \& Tseng, C. H. (2005). The performance of marketing alliances between the tourism industry and credit card issuing banks in Taiwan. Tourism Management, 26(1), 15-24. DOI: 10.1016/j.tourman.2003.08.018.

Czech Statistical Office. (2015). Public Database [statistics]. Retrieved from https://vdb2.czso.cz/ vdbvo2/faces/en/index.jsf

Dredge, D. (2006). Policy networks and the local organisation of tourism. Tourism Management, 27(2), 269-280. DOI: 10.1016/j.tourman.2004.10.003.

Erkus-Öztürk, H. (2009). The role of cluster types and firm size in designing the level of network relations: The experience of the Antalya tourism region. Tourism Management, 30(4), 589-597. DOI: 10.1016/j.tourman.2008.10.008.

Gibson, L., \& Lynch, P. (2007). Networks: comparing community experiences. In E. Michael (Ed.), Micro-Clusters and Networks: The growth of tourism (pp. 107-26). London: Elsevier.

Grängsjö, Y., \& Gummesson, E. (2006). Hotel networks and social capital in destination marketing. International Journal of Service Industry Management, 17(1), 58-75. DOI: $10.1108 / 09564230610651589$.

Halme, M. (2001). Learning for sustainable development in tourism networks. Business strategy and the environment, 10(2), 100-114. DOI: 10.1002/bse.278.

Holešinská, A. (2007). Destinačni management aneb Jak ř́́dit turistickou destinaci (Destination management or How to manage a tourist destination). Brno: Masaryk University.

Holešinská, A. (2012). Destinačni management jako nástroj regionálni politiky cestovního ruchu (Destination management as an instrument for regional tourism policy). Brno: Masaryk University.

Holešinská, A. (2013). DMO - A dummy-made organ or a really working destination management organization. Czech Journal of Tourism, 2(1), 19-36. DOI:10.2478/cjot-2013-0002.

Holešinská, A. (2014). DMOs' cooperation with stakeholders. In Holešinská, A. (ed) 5th International Colloquium on Tourism. Proceedings. Pavlov, 11-12 September 2014. CD-ROM (pp 55-65). Brno: Masaryk University.

Kozak, M., Crotts, J. C., \& Law, R. (2007). The impact of the perception of risk on international travellers. International Journal of Tourism Research, 9(4), 233-242. DOI: 10.1002/jtr.607.

Kozak, M., \& Baloglu, S. (2010). Managing and marketing tourist destinations: Strategies to gain a competitive edge. New York/Abingdon: Routledge. 
Kylänen, M., \& Rusko, R. (2011). Unintentional coopetition in the service industries: The case of Pyhä-Luosto tourism destination in the Finnish Lapland. European Management Journal, 29(3), 193-205. DOI: 10.1016/j.emj.2010.10.006.

Nordin, S., \& Svensson, B. (2007). Innovative destination governance: The Swedish ski resort of Åre. The International Journal of Entrepreneurship and Innovation, 8(1), 53-66. DOI: $10.5367 / 000000007780007416$.

Page, W. H., \& Lopatka, J. E. (1999). Network externalities. Encyclopedia of law and economics, 760, 952-980.

Pechlaner, H., \& Tschurtschenthaler, P. (2003). Tourism Policy, Tourism Organisations and Change Management in Alpine Regions and Destinations: A European Perspective. Current Issues in Tourism, 6(6), 508-539. DOI: 10.1080/13683500308667967.

Ritchie, J. B., \& Crouch, G. I. (2003). The competitive destination: A sustainable tourism perspective. Wallingford/Cambridge: CABI Publishing.

Swarbrooke, J. (2005). Sustainable tourism management. Cambridge: CABI Publishing.

Tinsley, R., \& Lynch, P. (2001). Small tourism business networks and destination development. International Journal of Hospitality Management, 20(4), 367-378. DOI: 10.1016/S02784319(01)00024-X.

Volgger, M. \& Pechlaner, H. (2014). Requirements for destination management organizations in destination governance: Understanding DMO success. Tourism Management, 41, 64-75. DOI: 10.1016/j.tourman.2013.09.001.

Vystoupil, et al. (2006). Atlas cestovního ruchu České republiky (The Tourism Atlas of the Czech Republic). Prague: Ministry for Regional Development of the Czech Republic.

Wang, Y., \& Fesenmaier, D. R. (2006). Identifying the success factors of web-based marketing strategy: An investigation of convention and visitors bureaus in the United States. Journal of Travel Research, 44(3), 239-249. DOI: 10.1177/0047287505279007.

Weiermair, K., Peters, M., \& Frehse, J. (2008). Success factors for public private partnership: cases in alpine tourism development. Journal of Services Research, 8(Special Issue), p 7. 